\title{
Deflexed Fetal Attitude
}

National Cancer Institute

\section{Source}

National Cancer Institute. Deflexed Fetal Attitude. NCI Thesaurus. Code C92765.

A position of the fetus during the labor and delivery process where the fetal back is straight, the head position is deflexed and upright on the spine. 